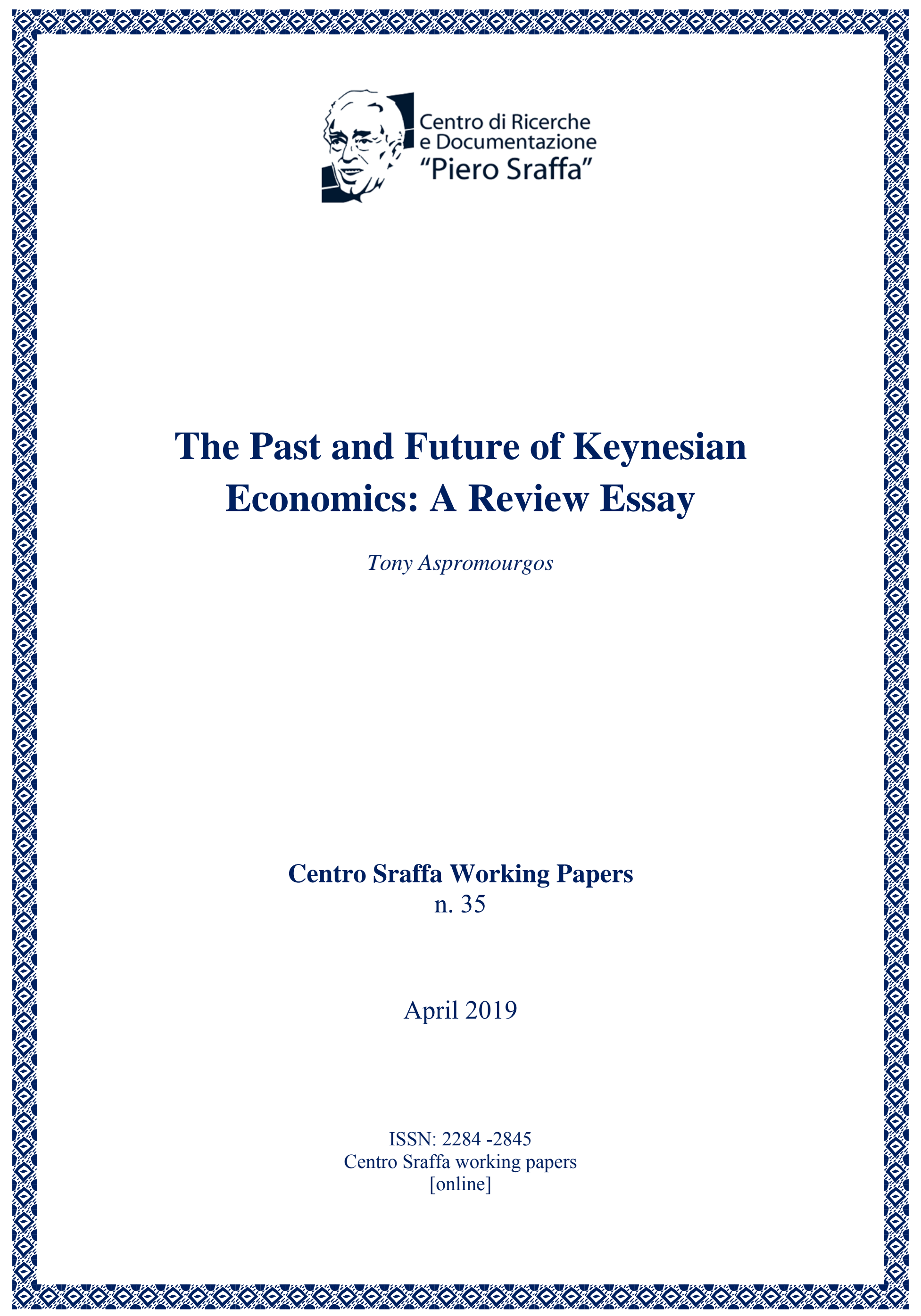




\title{
The Past and Future of Keynesian Economics: A Review Essay
}

\author{
Tony Aspromourgos \\ University of Sydney
}

\begin{abstract}
The recently published Elgar Companion to John Maynard Keynes (2019) is a major new contribution to Keynes scholarship, with sixty-three participants contributing ninety-five distinct entries, in 632 pages of text proper. This review essay provides an overview and assessment of the character and content of the work. It does so also via consideration of the question of Keynes's key theoretical achievements; the relation between Keynes's thought and the main currents of subsequent Keynesian economics; Keynes's policy sensibility vis-à-vis 'Keynesian' policy; and finally, the question as to what is of enduring validity and greatest importance in Keynes's economics, for the future.
\end{abstract}

Keywords: John Maynard Keynes; Keynesianism; Pierangelo Garegnani.

JEL codes: B22; B31.

\section{Introduction}

It is something of a mixed blessing for John Maynard Keynes, that he is one of a small number of economists whose name and image resonate, beyond the academy, in the mind and imagination of a wider public - the other two prominent cases being, of course, Adam Smith and Karl Marx. It is rather 'neat' in a way, that these three in particular should inhabit this larger public consciousness. Smith, Marx and Keynes can be conceived of as representing the three contending politico-economic doctrines that have dominated socio-political debate and conflict since the nineteenth century: liberalism, socialism and social democracy. It is also unsurprising that, unique among the social sciences, it is political economy or economic science that has at least a small number of its thinkers so salient in general public discourse. It is the unique ideological importance of economics - its potential for rationalizing or questioning the distribution of material resources in society - that is the reason for this. 
But it is a consequence of this larger status that the images of these thinkers also easily become distortions and parodies vis-à-vis the reality of what they were and what they thought, as ideological purposes and conflicts almost inevitably debase the currency of debate, public and academic. Marx apparently was once moved to declare he was not a Marxist (Institut 1967, 388) and Keynes distanced himself from at least some Keynesianism (Robinson 1977, 58). Hence the task and value of scholarship in relation to such figures is, in part, to recover the genuine person and the authentic voice - rather like 'the quest for the historical Jesus' - and to compare all that to the character of the subsequent school or schools of thought generated by the person's writings. The major new contribution to Keynes scholarship under review here ably tackles that kind of goal, and more. ${ }^{1}$ In the editors' own words, the work covers: 'aspects of Keynes's life and career, influences on his intellectual development, his major writings, themes in his analytical contributions, significant contemporaries with whom he interacted, later figures whom he influenced, and what became of his ideas and legacy in various countries' (2; throughout, page numbers that appear on their own in parentheses refer to the pages of the Companion). The work might even have been entitled the 'Elgar companion to Keynes and Keynesian economics', since it includes a large number of essays on the figures and forces involved in the making of Keynesian economics. It seems an overstatement of the editors to say that 'the whole of The Elgar Companion to John Maynard Keynes is, in one way or another, only about him' (3).

It is also notable, and surely not an accident or coincidence, that all three of these most salient of the political economists were much more than merely economists, and much more than mere theorists - and in the case of the latter two at least, much more than mere intellectuals. When Robert Skidelsky began his three-volume, comprehensive biography of Keynes, there were those in the economics fraternity who looked askance at such a project being undertaken by a non-economist. But in truth, because Keynes is much more than an economist, he deserves to be appraised and interpreted also by more and other than mere economists. Keynes's life and thought is a very large and multidimensional subject. To understand it we need to hear from multiple interpretive voices and the Elgar Companion certainly provides that. This review essay is divided into five sections, considering in turn, the overall character and content of the collection (section 2); the question of Keynes's key theoretical achievements (section 3); the relation between Keynes's thought and the main currents of subsequent Keynesian economics (section 4); Keynes's policy sensibility vis-à-vis 'Keynesian' policy (section 5); and finally, the future of Keynesian economics (section 6).

\footnotetext{
${ }^{1}$ Robert W. Dimand and Harald Hagemann (eds), The Elgar Companion to John Maynard Keynes, 2019, Cheltenham, UK and Northampton, MA, USA: Elgar, ISBN 9781847200082 (hb); 978178811 8569 (eBook). Pp. xxi +648. $2235.00 / \$ 350.00(\mathrm{hb}) ; £ 48.00 / \$ 65.00$ (eBook).
} 


\title{
2. Structure and Organization of the Work
}

There are ninety-five entries authored by sixty-three contributors, in 632 pages of text proper; hence, the average length of the chapters is six and a half pages. The collection is divided into eight Parts, as indicated below, showing also, for each section, the number of entries (E), the average page-length (p), and the section's proportion of the overall text proper $(\%)$ :

\author{
I. 'Life and Work' (9E, 7p, 10\%) \\ II. 'Influences' (9E, 5.3p, 8\%) \\ III. 'Major Works' (13E, 6p, 13\%) \\ IV. 'Economic Analysis' (17E, 6.2p, 17\%) \\ V. 'Critics and Contemporaries' (9E, 7.3p, 11\%) \\ VI. 'Associates' (9E, 6.4p, 9\%) \\ VII. 'Legacy and Impact' (21E, 6.2p, 21\%) \\ VIII. 'Keynesianism in Various Countries' (8E, 8.3p, 11\%)
}

As this shows, putting aside the country studies, the average chapter lengths do not differ greatly across the eight sections; the highest of the remaining section averages (Part V) is 38\% greater than the lowest (Part II). I think this average length is a welljudged editorial decision: the resulting essays are neither mere encyclopaedia-style thumbnail sketches, nor full academic-length articles, but something in between. This is ideal for a reference work for the reader who wants a compact but not insubstantial account of the subject. (The Companion averages about 600 words per page.)

Five contributors have the honour or burden of more than two entries: Mauro Boianovsky (three; one co-authored with Charles Goodhart), John Davis (four), Don Moggridge (five) and the two editors (eighteen between them, all single-authored). A further twelve contributors have two chapters each. So that eighteen people have provided fiftyfour of the ninety-five entries. It is striking that Parts II and V-VII are almost entirely organized in terms of chapters on specific persons - natural in the case of the Parts $\mathrm{V}$ and VI, and fairly natural in the case of Part II, but not so obvious an approach to take in the case of Part VII. In fact, Part VII is the partial exception among these four sections, since along with seventeen person-entries, it also includes chapters on 'Post-Keynesian economics' (Eckhard Hein and Marc Lavoie), 'New Keynesian macroeconomics' (Peter Spahn) and 'The Phillips curve' (James Forder), and Peter Clarke on 'The rise, fall, and return of the master'. The latter emphasizes the revolutionary intent and genuine revolutionary character of Keynes's 1930s economics, ${ }^{2}$ and more broadly, the two-way, often

\footnotetext{
${ }^{2}$ Clarke (561) in this context quotes a 1 January 1935 letter of Keynes to George Bernard Shaw: '... I believe myself to be writing a book on economic theory, which will largely revolutionise [...] the way the world thinks about economic problems' (Moggridge et al. 1971-1989, vol. XXVIII, 42). This work is hereafter cited as $C W$, with relevant volume number. As a second-year undergraduate in 1975, I purchased the 1970 'Papermac' paperback edition of the General Theory, which quotes this, and more of
} 
'symbiotic', relationship between theory and policy in the development of his thinking (562). Clarke's title echoes that of Clarke (2009) - which I recommended in my seventy-fifth anniversary essay on Keynes as 'the best available short account of Keynes's life and thought as a whole' (Aspromourgos 2012, 155n) - and the title of Skidelsky (2009). Part I also has three person-entries, devoted to Keynes's parents and his wife, as well as a chapter on the Bloomsbury Group (a persons-entry, plural, one might say). Hence altogether, these person-entries amount to around half of the whole text. I think it can be said that the cast of characters covered in these person-entries are 'the usual suspects' (this is not a criticism), with the notable exception of Mabel Timlin (Dimand).

The 'Economic Analysis' section also is presented in terms of largely predictable themes arising out of Keynes's mature economic thought (again, this is not a criticism). Perhaps not so predictable in this section is the inclusion of chapters on 'The KeynesSraffa-Hayek controversy' (Heinz Kurz), the Keynes-versus-Tinbergen econometrics issue (Marcel Boumans) and 'Mercantilism' (Lars Magnusson). The 'Major Works' section is an unusual and very nice idea. Of its thirteen entries, eight are devoted to eight of Keynes's nine major books: the six obvious ones plus Essays in Biography (G.C. Harcourt) and How to Pay for the War (Spahn). Hence there is no chapter on A Revision of the Treaty or Essays in Persuasion; but the latter is covered, so to speak, by four of the remaining five entries addressing what are probably the four most significant essays in that 1931 volume: The Economic Consequences of Mr. Churchill (Dimand), 'The End of Laissez-Faire' (Sherry Davis Kasper), 'Am I a Liberal?' (Dimand) and 'Economic Possibilities for our Grandchildren' (Hagemann). The only possible other contender for a chapter, from that volume, would have been the 1929 pamphlet, 'Can Lloyd George Do It?', co-authored with Hubert Henderson - discussed in any case in the Part IV entry on 'The multiplier' (Dimand). The one further chapter in section III is devoted to four years of student notes of Keynes's Michaelmas term lectures from 1932 to 1935 - obviously a crucial period in the development of Keynes's thinking - as edited and synthesized by T.K. Rymes: "Lectures on "The Monetary Theory of Production" [the title Keynes used in 1932 and 1933] and "The General Theory of Employment" [the title in 1934 and 1935]' (Dimand). The author regards these student notes as 'comparable in importance and fascination to the rediscovered lecture notes of Adam Smith' (181; referring to Meek et al. 1978). It may be added here also that Skidelsky has what is perhaps the 'prize' entry in the entire collection, the chapter on the General Theory; but Moggridge has four entries in Part I, covering almost the entirety of Keynes's adult life, from 1906 forward.

One final issue may be mentioned here. In a large, wide-ranging collective work of scholarship like this, the index can be an important element of the editorial contribution, serving as a valuable tool for readers to search for specific topics other than those ex-

Keynes's letter, on the back cover, as a kind of self-penned advertising blurb. I still possess that (now considerably battered!) copy. 
plicit in the ninety-five subjects of the chapters. However, the usefulness of an index is not easy to assess in a review. Moreover, the advent of machine-readable e-text has diminished the importance of indexes, since the reader can thereby rather easily and at low cost become her own indexer, at least for pursuit of just a small number of particular topics. On the other hand, editors' conceptualizations of content via the organization and subdivisions of an index can highlight themes readers might otherwise overlook. ${ }^{3}$ One test of the index for a subject matter not explicit in any of the ninety-five topics of the entries is to assess it with respect to Keynes in relation to policy and politics ${ }^{4}-$ and with respect to policy as such. I have undertaken that exercise by electronically searching the entire text for 'poli' - thereby capturing all references to policy and politics and compared the findings with what the index offers by way of page references under that part-term (in both entries and subentries). Without going into tedious detail, my conclusions are that the index is sound and usefully organized in relation to policy but not in relation to politics. 'Politics' has an index entry with just one reference (500). This involves, literally, a reference to 'politics' but it is a mere passing comment. Far more significant discussion of Keynes and politics is missed, most notably, Clarke's chapter (in which, incidentally, the word 'politics' explicitly appears on every page) and there are other important politics-related commentaries (see the penultimate paragraph of section 5 below).

\section{Keynes's Key Theoretical Achievements}

What do the relevant contributors to this collection regard as Keynes's key theoretical achievements in economics?

Skidelsky's General Theory entry frames Keynes's abandonment of orthodoxy in terms of rejecting the causal significance of money and the efficacy of monetary policy. His central constructive achievement is 'the theory of effective demand', in which changes in aggregate output and income equilibrate the macroeconomy, with a consequent capacity for 'under-employment equilibrium', and not only in the short run. Skidelsky sees uncertainty as playing a crucial role in explaining suboptimal levels of

\footnotetext{
${ }^{3}$ The index can assist even for topics which have a designated entry. For example, along with the chapter on Keynes and econometrics, there is also important comment on this issue elsewhere in the Companion (in particular, 420-21). In fact, the 'econometrics' index entry is very sound, missing only one significant reference: the report of Lawrence Klein's comment that Keynes's critique of Tinbergen (1939) was 'one of his sorriest professional performances' (469).

${ }^{4}$ Or at least, Keynes's politics can be considered just as it connects with his economics, keeping in mind the editors' mandate for the Companion: 'our focus is on the influences upon, contributions of and legacy of an economist, both economic theorist and political economist' (3; emphasis added). The substance of Keynes's politics with respect to economic matters was to seek a 'middle way' between liberalism and socialism (Aspromourgos 2012, 152; Companion, 154, 157). Dimand's 'Am I a Liberal?' chapter well captures Keynes's self-understanding of his position in the conventional political spectrum of his time (also 197-9).
} 
aggregate demand and 'the neoclassical remedies' are thoroughly deprived of theoretical justification (190). Moggridge also highlights the consumption function and 'the theory of effective demand', which together 'emphasise the equilibrating role of changes in output implicit in the multiplier' ('Keynes and British financial policy in the interwar period'; 48). The actual chapter on 'Effective demand' (Paul Davidson) also makes uncertainty crucial, but is very slight and quite unsatisfactory, with the associated aggregate demand and supply functions underspecified, so that neither the uniqueness nor the stability of 'the point of effective demand' are justified. Volker Caspari indicates how Keynes's consumption function, together with the multiplier, generates 'Keynes's new perspective on the causalities between macroeconomic magnitudes', with 'the balance of savings and investment ... secured by the level of income and not by the rate of interest' ('Consumption and saving'; 244). The logic of saving-investment equilibration via the multiplier also plays a crucial role in Jan Kregel's entry on 'The finance motive': investment expenditure presupposes finance not saving. Dimand's multiplier chapter provides a very careful reconstruction of the history of the concept, especially for the period up to 1933, but does not much attend to its role as a mechanism for the equilibration of investment and saving in general - which is what turns it into a principle of fundamental importance for the theory of aggregate activity levels, rather than merely a tool for fiscal policy analysis.

Taking a rather different angle, Victoria Chick ('Liquidity preference'), following G.L.S. Shackle, makes liquidity preference the vital factor for explaining the possibility of involuntary unemployment. The rate of interest is determined by reference to money demand an inverse function of the actual rate of interest, generated by speculative demand for money a function of the relation between actual interest rates and speculators' conceptions of the uncertain 'normal or safe rate'. The explanation for involuntary unemployment reduces to the proposition that liquidity preference can hold the interest rate above an implied full-employment rate (251-2). Sylvie Rivot's entry on 'Unemployment' also looks to money or financial market failure as the cause of involuntary unemployment. (She also shows that 'any [...] unemployment [...] associated with imperfections in the labour market' - notably, 'rigidities either in nominal or real terms' is included by Keynes under the concept of voluntary unemployment.) The problem is 'the lack of a coordination mechanism between the intertemporal plans of savers and of investors, 5 associated with 'an interest rate so low that further falls are simply not feasible'. Rivot goes on to say that 'nominal rigidities are absolutely not at stake here', apparently intending only the labour market, because 'downward rigidity of the interest rate', 'a floor to the equilibrium interest rate', plays an essential role in her argument (228-9). Dimand mentions Ralph Hawtrey's also having 'identified... [Keynes's] crucial advance... as liquidity preference' (215).

\footnotetext{
${ }^{5}$ One could alternatively express this as the lack of a coordinating mechanism between the level of saving associated with the full-employment level of aggregate output and the level of investment.
} 
At odds to some extent with these latter views in particular, my own view is that Keynes's two key (and connected) theoretical innovations are: aggregate economic activity levels as demand-determined, rather than supply-side determined; and the general level of interest rates as determined by convention and monetary forces, rather than by 'real' forces (hence, non-neutrality of money). The former is the principle of effective demand, which entails - and so, may alternatively be expressed as - the proposition that investment determines saving via a multiplier mechanism acting through aggregate output and income. (For the multiplier mechanism in a supply-constrained economy, see 196.) The connection of Keynes's interest rate determination to the principle of effective demand is indicated with clarity in Keynes (1937, 250 or CW XIV, 212; Kregel also draws attention to this line of argument: 268):

... the initial novelty [of Keynes's theory] lies in my maintaining that it is not the rate of interest, but the level of incomes which ensures equality between saving and investment. The arguments which lead up to this initial conclusion are independent of my subsequent theory of the rate of interest, and in fact I reached it before I had reached the latter theory. But the result of it was to leave the rate of interest in the air. If the rate of interest is not determined by saving and investment ... how is it determined?

Keynes goes on to state a variant of his liquidity preference idea, including the comment, 'this by itself does not carry us very far'. ${ }^{6}$ His diffidence deserves to be taken seriously. Keynes's treatment of interest is better thought of as a conception of the normal level of the rate of interest as given by convention, presented most clearly in an important passage of argument in Keynes (1936, 202-04): the general level of interest rates arises out of the interaction between the psychology (interest rate expectations) of the money markets, embodying notions of a 'normal' rate, and central bank interest rate policy. Keynes believed that if the central bank pursued policy in a manner measured, steady, consistent over time, and therefore, credible in the markets, by thereby shaping interest rate expectations, it could enforce its will with respect to the general level of interest rates. Monetary policy could determine the conventional conception of the "normal' level of the rate of interest.

Hence, for example, in Chick's argument, where does the average opinion as to the 'normal or safe rate' of interest (251) come from? How is it determined? This belief is purely conventional - necessarily a mere product of the history of interest rates. How could it be otherwise, when there is no objective basis for a unique equilibrium rate of interest? From this perspective, liquidity preference merely serves as the factor giving stability to the normal rate, conventionally determined, by way of generating stabilizing variations of money demand (Panico 1988, chapter 4: 'Keynes on the Interest Rate', especially 128-32; Aspromourgos 2007; for Piero Sraffa's reaction to Keynes on this matter, Aspromourgos 2004b, 227-8). This gets to the heart of the issue better than the

\footnotetext{
${ }^{6}$ And elsewhere in the same article: "To speak of the "liquidity-preference theory" of the rate of interest is, indeed, to dignify it too much' (CW XIV, 215). See also Malcolm Sawyer's chapter on Michał Kalecki, for the accord between my interpretation of Keynes's two innovations and Kalecki's view (371-2).
} 
characterization of Keynes's position in terms of interest 'as a purely monetary phenomenon' (252). Furthermore, the idea that demand deficiency and the associated unemployment are merely due to liquidity preference keeping the interest rate above a supposed full-employment rate is highly implausible, and hardly amounts to a 'revolution' in economic theory. ${ }^{7}$ It may be acknowledged that money and the monetary economy are vital to the principle of effective demand in a more elementary sense: that the existence of such a store of abstract value is a precondition for the separation of saving decisions and investment decisions. Hagemann's 'Say's Law' entry is good on this.

In a world of transparent interest-rate-setting monetary policy, what is to stop policy setting any real rate of interest it wants, including a negative rate? Given the lower bound at which the nominal rate can be set - zero or perhaps somewhat lower - the only obstacles would appear to be either an incapacity of policy to achieve the required inflation rate, or the required inflation rate conflicting with some other policy objectives. For a robust approach to effective demand it is better to reject the notion of aggregate expenditure (in particular, investment) as a well-defined and robust negative function of the interest rate - persistent with respect to the long-run behaviour of the system - and the associated concept of a well-defined and unique full-employment rate of interest. Of course there is a notion like this in the General Theory (e.g., 1936, 31, 202, 242-4, 267), so that this entails walking away from an element of Keynes's system - but in order to strengthen it (Petri 2004, chapter 7: 'Capital theory and macroeconomics. I: the theory of aggregate investment'). Keynes's acquiescence in this notion opened the door to an emasculation of his theory. Kregel's chapter on 'Investment, expectations and the marginal efficiency of capital' does not at all address how, starting from Keynes's conceptualization of the individual investment decision, one may coherently arrive at his negatively-sloped aggregate investment demand function. Of course, it is also true that in a system that does have an economically meaningful and unique full-employment equilibrium, disequilibrium wage-price dynamics may be incapable of restoring equilibrium (Hagemann, 'Wages and employment').

\section{Main Currents of Keynesianism}

In teaching a semester course of lectures and seminars devoted to the General Theory, to advanced students over many years, I have sought to succinctly approach the question of how, post-1936, the discipline went about 'digesting' Keynes's attempted revolution, in terms of three sets of responses: a) more or less complete rejection of Keynes

\footnotetext{
${ }^{7}$ Rivot appeals to 'a very low marginal efficiency of capital' as well as 'a very high liquidity-preference schedule' (229; compare 501, in her 'Milton Friedman' entry). To be clear, ultimately these kinds of conceptualizations of demand deficiency involve a relation between the liquidity-preference-determined interest rate, the expected profitability of aggregate investment given by the marginal efficiency of capital schedule, and the full-employment level of aggregate saving. See also Kurz's 'Sraffa-Hayek' entry, $277-81$.
} 
and reaffirmation of traditional marginalist theory; b) combining Keynes and marginalism in some manner or other; and c) endorsing, and to some extent or other radicalizing (in the sense of theory, not politics), Keynes's doctrine, by a more thoroughgoing rejection of marginalism (more thoroughgoing than both the second response and Keynes himself). In the first instance the most influential element of the second set of responses was the conventional Keynesianism of the immediate post-war decades and the associated IS-LM framework, subsequently succeeded by New Keynesian economics. Most, but not all, of those who took the third route ended up under the banner of PostKeynesian economics. Is this trichotomy adequate for comprehending all of the cast of characters in Parts V-VII of the Companion? (They are all economists.)

Let us start with those, with entries on them in the Companion, who rejected Keynes and Keynesianism. The personification of orthodoxy in Keynes's General Theory criticism, and greatly aggrieved by that treatment, Arthur Pigou, unsurprisingly, reacted negatively to the book. Although finally making some concession to Keynesianism - he accepted the IS-LM framework, with a real balance effect - Pigou held firm to the view that cyclical unemployment (attributed to demand deficiency and changes in the composition of aggregate demand), even if of 'long duration', is nevertheless only 'intermittent' or 'transient'. The long-run tendency is to full employment, unless obstructed by wage inflexibility (Nahid Aslanbeigui and Guy Oakes; 309-10, 314; compare Dimand 1991). Dennis Robertson, earlier a student and collaborator of Keynes, ended up a sniping critic of Keynesianism, reinforced by his being 'temperamentally conservative'; and the authors conclude that ' $[\mathrm{m}]$ ainstream macro is now Robertsonian, rather than Keynesian' (Boianovsky and Goodhart; 317, 321). David Glasner's entry on Ralph Hawtrey has him vindicated, against Keynes, by the subsequent 'weight of professional opinion', on the saving-investment equality, liquidity preference and nominal wage flexibility (339). Hawtrey was also the author of 'the Treasury view' notion of crowding out (341). Friedrich Hayek's opposition to the Keynes of the General Theory and after, is presented in terms of 'structural mismatch' explanations for booms and crises (as against aggregate supply-demand analysis); disequilibrium as 'an informational problem' of 'disturbed' price signals; animosity to aggregate analysis (in favour of 'subjectivism' and 'methodological individualism'); and of course, divergent socio-political convictions (Hansjörg Klausinger; 351-2). There is also Rivot's Friedman chapter.

As to those who sought to synthesize Keynes and marginalism, John Hicks is the unchallengeable dominant founding figure, particularly due to his invention of IS-LM. Unfortunately, the Hicks entry, while aiming to show the difference between Keynes and Hicks's Keynesianism, does not succeed, is garbled at many points, and with much misrepresentation of Keynes's views (Omar Hamouda). Alvin Hansen played a key role in the intellectual diffusion of the Hicksian interpretation, and in the making of American Keynesianism more broadly, including stimulating development of the multiplier- 
accelerator model (Roger Backhouse; 451-2, 454). ${ }^{8}$ Backhouse's entry on Paul Samuelson makes evident his even more important role in the making of post-war, especially American, Keynesianism, including formalizing the multiplier-accelerator interaction, developing the Phillips curve framework, and disseminating the 'neoclassical synthesis' to generations of undergraduates via his textbook (462-4) - a term, indeed, coined by Samuelson (Aspromourgos 1986; compare Companion, 486, note 3). Lionel Robbins initially resisted the Keynesian revolution but eventually came round to a position 'essentially that of the post-war "neoclassical synthesis" (Susan Howson; 336). HansMichael Trautwein's 'Bertil Ohlin' chapter leaves open the question of the extent to which the Stockholm School, inspired by Knut Wicksell, anticipated 'the core' of the General Theory, depending as it does on one's conception as to what that core is. At best, I would judge it only to amount to something akin to the neoclassical synthesis. But the incorporation into Keynesian economics of the Stockholm distinction between ex ante equilibria and ex post identities certainly corrected some conceptual confusion in Keynes's own formulations (359-60). Other figures with entries, who may also be regarded as embracing some variant or other of a Keynes-marginalism synthesis, include Timlin, Roy Harrod, David Champernowne, Franco Modigliani, James Tobin, Don Patinkin, Harry Johnson, Robert Solow, Robert Clower and Axel Leijonhufvud (there is also a chapter on IS-LM, by Young). Although it was James Meade who first grasped how the multiplier acted as a saving-investment equilibration mechanism, as indicated in Howson's Meade entry (408), in the end he was also a synthesis Keynesian (410). ${ }^{9}$

Then, finally, there are the more radical Keynesians. The Post-Keynesian economics chapter lists no less than five strands in that school: 'fundamentalist', Kaleckian, Sraffian, Institutionalist and Kaldorian - with major themes including effective demand, 'fundamental uncertainty', financial instability, 'cost-plus pricing', class conflict, growth, multi-sectoral production systems, capital theory, 'long-run positions of the economy', theory of the firm, monetary institutions and 'productivity regimes'. One is led to wonder whether this is a case of 'the enemy of my enemy is my (Post-Keynesian) friend'; that all that unites these intellectual communities is their opposition to orthodoxy. But there are opponents of orthodoxy not included. (Post-Keynesianism is explicitly treated as a subset of heterodox economics.) There is a positive unifying core suggested, which indeed amounts to a Keynesianism purged of marginalist methodology

\footnotetext{
${ }^{8}$ Dimand's chapter on the 1930s lectures shows that Keynes was at least contemplating a simultaneousequations formulation of his system prior to the General Theory (where no such formulation was employed). This is quite similar to the IS-LM representation of his system, but with long-period expectations a parameter in the liquidity preference, consumption and investment functions (183-4). Warren Young wonders whether Keynes's apparent endorsement of IS-LM, or IS-LM-like models, was a sort of strategic decision, to advance his doctrine via a form congenial to the profession (263).

${ }^{9}$ The notion of Keynesian demand deficiency as a form of more or less persistent disequilibrium also belongs in the synthesis category, since ultimately entailing acquiescence in the notion of a supply-sidedetermined full-employment equilibrium. See the chapters on Tobin (Dimand; 491), Patinkin (Goulven Rubin; 509-12), Solow (Michaël Assous; 483, 485), and the Clower (Peter Howitt) and Leijonhufvud (Trautwein) entries in their entirety.
} 
and theory, with non-neutrality of money and demand-driven activity levels in the short run and the long run (541-3). Figures with entries who may be regarded as in the radical-Keynesian category include Richard Kahn, Joan Robinson, George Shackle, Nicholas Kaldor, Lorie Tarshis, Sidney Weintraub, Hyman Minsky - and perhaps, and belatedly, William Beveridge. Bruce Littleboy's Shackle chapter ably clarifies his relationship to both Keynes and Austrian economics, and rescues him from the accusation of theoretical nihilism (at least of a thoroughgoing kind). Randall Wray's Minsky entry is also particularly illuminating, concerning his thought as a whole, not just the famous financial instability hypothesis.

My suggested fundamental divide in the currents of Keynesianism, between the synthesizers and the radicals, is in part an expression of the character of the General Theory itself: Keynes's literal argument there is an unstable compromise between the unorthodox message of the principle of effective demand and his acquiescence in various marginalist postulates - in particular, marginal productivity theory (Garegnani 1978-79, 77). To extract from it a completely coherent doctrine, one had to either retreat to a more orthodox position or advance to a more radical one. The figures with chapters in Parts V-VII, who do not comfortably fit into my trichotomy (at least on the basis of the accounts of them provided there) are Sraffa, Kalecki, Colin Clark, Richard Stone, Klein and perhaps Joseph Schumpeter - although I suppose one could call Kalecki a radical 'Keynesian'! Schumpeter's ambivalence, indeed antipathy, towards Keynes is at least as much due to their difference in intellectual focus or level of analysis - Schumpeter's concern with the evolutionary capitalist dynamics of technical progress, innovation and structural change - as to their differences of theoretical opinion, although there is certainly that as well (entry by Hagemann; especially 329). These dynamic and structural phenomena, in any case, can be grafted onto a fundamentally Keynesian system (e.g., Pasinetti 1981; Schefold 1997; Cesaratto et al. 2003; Pasinetti 2007; Smith 2012). The most striking 'sin of omission' with respect to Parts V-VII is the absence of a chapter devoted to Pierangelo Garegnani, which could have provided both an account of his important constructive contributions to the demand-side theory of activity levels and critical consideration of the capital-theoretic dimension of the General Theory (more on this in section 6 below) - although Kurz's Sraffa entry deals considerably with the latter critical aspect (380-85). To a lesser extent, one wonders whether Evsey Domar might not also have warranted a chapter.

\section{Keynes’s Policy Sensibility and 'Keynesian’ Policy}

That there is a disjunction between Keynes's policy views and what became 'Keynesian' economic policy in the post-war decades is not a new idea. I have elsewhere made my own effort to show the distance between the two (Aspromourgos 2012). Rivot rightly emphasizes that Keynes's views entail 'state intervention ... much more comprehensive than counter-cyclical schemes and deficit spending'; 'prevention [of unemploy- 
ment] ... instead of cure'; 'focus on ...investment ... rather than ... consumption'; 'and, above all, a focus on long-term schemes' (231). This is in contrast to mere short-run, discretionary countercyclical fiscal (and perhaps monetary) policy, associated with postwar synthesis Keynesianism (e.g., see 408-09, 463, 490, 588). ${ }^{10}$ Rivot more or less repeats her view in the Friedman chapter but also asserts there that Keynes 'firmly opposed deficit budgeting' (503-04) - similar to Sawyer (372), appealing to Kregel (1985, 32). So baldly stated, this can easily be very misleading: Keynes was rather firmly opposed to deficit budgeting as he understood it - as an excess of recurrent expenditure over recurrent revenue - but he was not opposed to (at least partial) debt financing of capital expenditure (e.g., Keynes 1936, 128n; CW XXVII, 406; Brown-Collier and Collier 1995). Moggridge comments that the 'Keynesian macroeconomic approach to the problems of budgetary policy constitutes one of his most enduring contributions to the conduct of public affairs' (56) - as against mere public sector budget balancing. One should recall also that there are two fundamental objectives of economic policy for Keynes, posited in the opening sentence of the final, 'Social Philosophy' chapter of the General Theory $(1936,372)$, nowhere quoted in the Companion: 'The outstanding faults of the economic society in which we live are its failure to provide for full employment and its arbitrary and inequitable distribution of wealth and incomes'. Note the imputation of arbitrariness: not merely inequality, but arbitrary inequality, implying inequality without a basis in either justice or expediency (Aspromourgos 2015, 296, 300-02). How to Pay for the War is just one striking instance of Keynes's egalitarian temper in policy formulation (see Spahn's excellent entry; his 'New Keynesian macroeconomics' chapter is also very good).

Hein and Lavoie offer a statement of 'a consistent [Post-Keynesian] macroeconomic policy mix', short and long run, as an alternative to the orthodox 'new consensus' policy view; but it doesn't really amount to a singular, substantive alternative policy prescription - partly for good reason (the relevance of "concrete historical and institutional circumstances'), partly due to differences of opinion within the Post-Keynesian camp (543-5). In the spirit of Keynes, I would add: a permanent large, or permanently enlarged, public sector (or at least public spending) - under which, Keynes would include some decentralized 'semi-autonomous [public] bodies' (153; CW IX, 288, 300) - together with a 'to-do list' of capital works that can be readily activated or deactivated in response to short-run private sector fluctuations (Aspromourgos 2012, 150-51, 155-6).

\footnotetext{
${ }^{10}$ The question of monetary policy versus fiscal policy - in 2009 as much as 1929 - is not merely about the efficacy of the transmission mechanisms of the respective sets of policy instruments, let alone just the banal issue of the slopes of supposed IS and LM curves. From a conservative or economic-liberal standpoint, there is obvious ideological appeal in affirming the adequacy of monetary policy for successful achievement of desirable inflation and unemployment outcomes (leaving aside supply-side and otherwise structural unemployment): thereby, recourse to more interventionist economic governance and a more expansive public sector can be avoided and rejected. More than once Keynes entertains the possibility that military expenditure might be the only form of public expenditure, in magnitude sufficient for full employment, to which capitalism is amenable: CW XXI, 60 (from 1932), 293 (1933), 429 (1937), 532 (1939); Keynes (1936, 130); CW XXII, 149 (1940).
} 
In the environmental conditions we confront today, such public sector activity should have a 'Green infrastructure' focus, in the broadest sense of that term. A permanent policy of cheap money is also in the spirit of Keynes; in the limit, enforcing a zero real riskless rate of interest, although this most certainly requires very definite institutional (regulatory) conditions (Aspromourgos 2011; also 2004b). But even if there is agreement on the character of Keynes's theory, and that theory is endorsed, a singular agreed policy cannot be derived merely from that. The intervention of values is sufficient reason for there still to be policy disagreement; and there is also, for example, the issue of political and institutional preconditions for the efficacy of various policy regimes. Getting from even a singular, agreed-upon theory to a definite policy involves many contingencies. Sawyer notes Kalecki's proposition that a long-run full-employment policy requires either 'a long-run budget deficit policy' or 'redistribution of incomes' (372; Kalecki 1944, 135).

One may note parenthetically here that there is commonly a certain tension in synthesis Keynesianism, between its 'neoclassical' theoretical convictions and a relatively more Keynesian policy stance, perhaps no more strikingly epitomized than in the case of Patinkin (and in the aftermath of the Global Financial Crisis, evident in Lawrence Summers's revival of 'secular stagnation' and Paul Krugman's policy advocacy). This is well captured in Patinkin's $(1987,100)$ summary statement of the real-balance effect as a vindication of the notion of a full-employment equilibrium: "no one has ever advocated dealing with the problem of unemployment by waiting for wages and prices to decline ... the significance of the real-balance effect is in the realm of macroeconomic theory and not policy' (compare 193, 239). One may respond, 'some theory!', that is admitted to be inapplicable to the reality it purports to theorize. This dualism is rationalized by conceiving of involuntary unemployment as a long-lasting short-period phenomenon, or as a very persistent disequilibrium, or by construing the full-employment equilibrium as unstable with respect to nominal wage and price flexibility (with various forms of 'stickiness' contributing to the first two possibilities). One can, of course, endorse the proposition that downward flexibility of money wages in the face of involuntary unemployment would be contractionary, and deny that a competitive capitalist economy has a well-defined and economically meaningful full-employment equilibrium.

To return to Keynes, it is worth recalling also his mode of policy advocacy. As noted by Clarke, citing A Revision of the Treaty (CW III, 3-4), Keynes applied a conception of political engagement in pursuit of reform, via both 'inside' and 'outside' politics. The Essays in Persuasion are just one substantial expression of a larger role Keynes embraced, of public intellectual seeking to shape public opinion, in opposition to various orthodoxies, while at the same time also working directly to shift "the "inside opinion" of the well-informed circles who made policy' (562-3; see also 40, 54, 63, 65, 130, 151, 
195-200, 565). Hence Keynes was often simultaneously the outsider and the insider. ${ }^{11}$ Relevant to this also is that eight of the twelve chapters of the original 1933 Essays in Biography are devoted to 'Sketches of Politicians' - about twenty-nine per cent of the 1933 text proper (in the greatly expanded $1972 \mathrm{CW}$ edition, the figure is fifteen per cent). Whether Keynes's methods of persuasion with insiders were always quite so charming as his public writings and activities is a question. Richard Sayers (1976, 103n) relates, from a private interview, the judgement of Robert Boothby, 'that Keynes was the only man [Walter] Cunliffe ever feared'. ${ }^{12}$ In contemplating this intriguing comment, one should keep in mind that Keynes was nearly thirty years Cunliffe's junior, and still only thirty-four when Cunliffe's tenure as Governor ended. Howson (410) reports Meade's account of the last time he saw Keynes, in April 1946, the month Keynes died, involving a policy disagreement (Howson and Moggridge 1990, 250-51): 'It was a painful and distressing interview, in which I had to meet the whole battery of Keynes' wit, petulance, rudeness and quick unscrupulousness in argument. I was actually reduced to tears!' (In his entry on Stone, Ron Smith (421) comments: 'Stone, similar to James Meade, was a gentle soul and both found the combative and acrimonious atmosphere of Cambridge economics uncongenial'.) In contrast, Dimand (590) notes Robert Bryce's $(1988,150)$ account of Keynes's friendlier mode of inside persuasion in Canada in 1944: 'he was a very skilled negotiator, a very persuasive and fluent expositor; indeed his exercise of fluency and charm was so powerful that the Canadian ministers preferred to take their decisions after they had met with him, rather than while they were still under his spell.' From among the radical Keynesians, Kaldor is the one who most shares with Keynes the dimension of being a political insider (494-5).

Looking back over the course of Keynes's public life, the interventionist policy approach he advocated appears as having preceded in time a theory to justify it; so that one could cynically conclude that Keynes's 1930s theory was merely an elaborate rationalization for prior held political and policy convictions or prejudices. But there is an

${ }^{11}$ This may be contrasted with a rather different approach to the relation between the economist and politics, illustrated by the case of Summers. Speaking of a long evening spent with him, with a view to ironing out their differences over policy in the aftermath of the Global Financial Crisis, Elizabeth Warren writes:

Late in the evening, Larry leaned back in his chair and offered me some advice. ... He teed it up this way: I had a choice. I could be an insider or I could be an outsider. Outsiders can say whatever they want. But people on the inside don't listen to them. Insiders, however, get lots of access and a chance to push their ideas. People - powerful people - listen to what they have to say. But insiders also understand one unbreakable rule: They don't criticize other insiders.

I had been warned (Cassidy 2014, 6; reviewing and quoting Warren, A Fighting Chance).

Compare the very similar experience with Summers of Yanis Varoufakis $(2017,8)$.

${ }^{12}$ Cunliffe was Governor of the Bank of England, 1913-1918, and notorious for being an overbearing autocrat and bully. He was forced to resign by Chancellor of the Exchequer Bonar Law. See the entire section 5.E of Sayers (1976, 99-109: 'The Cunliffe Quarrel'). The Cunliffe/Keynes connection is touched upon in the Companion (36-8, 568), and Boothby and Keynes $(147,158)$. Cunliffe and Keynes also clashed over war reparations (Skidelsky 1983, 309, 339-41, 356-7, 364-6, 393; Moggridge 1992, 270-74, 306, 315). 
interpretation of this temporal sequence more favourable to Keynes, in which the theoretical revolution appears as providing a scientific basis for what were, in the first instance, just more or less sound intuitions. Schumpeter perceived the General Theory as the culmination of 'a long struggle' by Keynes to render 'analytically operative' a vision of England's ageing capitalism that is already in The Economic Consequences of the Peace (327-8; compare Daniele Besomi, 'Trade cycle', 290-91). Klein, in his influential book, The Keynesian Revolution, 'emphasized that Keynes's key contribution was not his advocacy of interventionist stabilization policy (which was by no means unusual), but instead was Keynes's revolutionary reorientation of economic theorizing ... that provided a basis for understanding why such policy might be needed and how it worked' (468-9; emphasis added). Keynes regarded himself as restoring to economics a consistency between theory and policy, commenting in 1937: 'Why do they insist on maintaining theories from which their own practical conclusions cannot possibly follow? It is a sort of Society for the Preservation of Ancient Monuments'. ${ }^{13}$ Moggridge quotes a beautiful statement by Keynes, the very month the General Theory was published, concerning the relation between conclusions, arguments and intuition:

The extent to which one sees one's destination before one discovers the route is the most obscure problem of all in the psychology of original work. In a sense it is the destination which one sees first. But then a good many of the destinations so seen turn out to be mirages. Only a small proportion of one's original intuitions survive the struggle of trying to find a route to them. ${ }^{14}$

\section{The Future of Keynesian Economics}

Reading every word of this remarkable collection, as I have, and in a rather short span of time, is a very rewarding experience; and it reminds one of the range of both Keynes's achievement and his influence. Probably not many (any?) others will wish to read it in its entirety. But for some or other of the various dimensions of the Companion, scholars who are inquiring into Keynes's life, thought, background, milieu, intellectual environment or impact would be most unwise not to consult this work. For those who would have recourse to just one or two chapters, and those who would seek to

\footnotetext{
${ }^{13}$ CW XIV, 259; compare CW XIII, 492; Keynes (1936, 20, 192). At another level, Keynes has a rather nuanced view of the relation between theory and practice; a conception of good policy practice as more than a mere mechanical application of sound theory. Elsewhere I have sought to capture this aspect of his policy sensibility, as expressed in one particular context (Aspromourgos 2014a; 2014b; 2018). In relation to proposals for post-war international economic institutions, Moggridge also notes that Keynes was 'sceptical ... of any merely mechanical application of doctrinal principles' (62).

${ }^{14}$ Moggridge (2010, xl), citing British Library Additional Manuscripts 57923, a letter to O.T. Falk, 19 February 1936; compare Keynes $(1936,371)$; CW X, 365 on Isaac Newton's 'muscles of intuition'. Cairncross (2004, 497; in the online edition, 4th-last paragraph of the text proper) recounts a very similar Keynes self-understanding of the role of intuition in his thinking, that Keynes articulated in his lectures. Robbins speaks of Keynes's 'bird-like swoops of intuition with which he opened up a subject' (564).
} 
work systematically through larger themes, this is a collection that every university economics library must have - and every student of Keynes must have, even if, for the latter at least, only in e-copy (given the hard-copy price). I conclude here, not with a prediction as to what will actually happen with Keynesian economics into the future, but rather, by addressing the (easier!) normative issue as to what directions a robust Keynesian economics ought now to take.

I noted, at the end of section 4 above, the omission from the Companion of an entry on Garegnani. In a series of important contributions he provided a rigorous critique of the orthodox capital-theoretic and functional-distribution dimensions of the General Theory, and pointed the way to a reconstruction of the principle of effective demand, purged of marginalist elements and applied to long-period economics and growth, as well as to short-period analysis. This involves combining the demand-side approach to activity levels with the classical or 'surplus' approach to functional distribution and prices. ${ }^{15}$ To the best of my knowledge there are only three approaches to price theory available for integration with the principle of effective demand: the conventional marginalist approach; the mark-up or 'cost-plus' pricing approach (notably associated with Kaleckian approaches to macroeconomics); and the classical-Marxian approach (which finds modern expression in Sraffa's rational reconstruction of classicism). In the framework of marginalist price theory the principle of effective demand suffocates, because that approach intrinsically connects the determination of quantities and prices with flexible prices, including factor prices, being supposed as bringing about marketclearing, including for factor markets. Demand-side determination of activity levels then inevitably becomes confined to mere short-period or otherwise temporary operation, due to the absence in that timeframe of price flexibility fully working its effects, or it becomes reliant upon persistent restrictions of one kind or another on price flexibility. On the other hand, the mark-up approach to pricing is rendered completely unsatisfactory by its inconsistency with the existence of produced means of production: the consequent simultaneous dependence of costs upon prices and prices upon costs means that there cannot be one-way causation from costs to prices (Steedman 1992). Hence, recourse to the classical approach to price theory appears to be the only viable option for a non-marginalist Keynesianism.

\footnotetext{
${ }^{15}$ See in particular, Garegnani $(1978-79 ; 1983 ; 1988 ; 1992)$ and Garegnani and Palumbo (1998). This research programme has generated a substantial literature. For just some pointers to this body of work, see Kurz (1985), the literature surveyed up to the beginning of the 2000s in Aspromourgos (2004a, 187, 189-90), Petri (2004), Levrero et al. (2013, Part I: seven papers on 'Demand-Led Growth in the Classical Approach'), and for a summary statement of the issues, Aspromourgos (2013, 23-8). There are only four passing references to Garegnani in the Companion $(218,377,542,614)$, the latter two of which - in the 'Post-Keynesian economics' and 'Keynesianism in Italy' (Piero Bini) chapters respectively - refer to the idea of a Sraffa-Keynes synthesis. Elsewhere, Lavoie (2013), in a welcome ecumenical spirit, has more fully endorsed a considerable compatibility between that intellectual project and Post-Keynesianism. But on the classical gravitation of market prices towards normal prices, compare his pages 39-43 with Bellino and Serrano (2018).
} 
The irreducible analytical core of demand-side determination of aggregate activity levels is the conceptualization of aggregate demand in terms of autonomous versus induced components - the former, autonomous in the sense of varying independent of realized income from current production; the latter, underpinning the multiplier. ${ }^{16}$ The particular content of the two categories is a distinct and further question. In the General Theory Keynes tended to identify autonomous demand with investment and induced demand with consumption. But the core logic of the principle of effective demand is consistent with both a degree of autonomy for consumption demand and part endogeneity of investment with respect to current income (e.g., via an influence of current business income on expectations of future profitability). For a thoroughgoing Keynesianism, the associated logic of activity levels determined by autonomous demand plus the multiplier will apply to the long run as well as the short run, so that growth will primarily be explained by the dynamics through time of the autonomous elements of aggregate demand. (While the multiplier may vary, it cannot be permanently increasing.) Growth economics will then be susceptible of only rather limited recourse to 'pure' or general theory, and will have to considerably rely upon theoretically informed economic history that takes into account the variety of institutional conditions.

The greater autonomy of consumption demand today, at least in high-income countries, relative to Keynes's world, is due to the household sector's now greater access to external financing, together with today's higher incomes giving greater scope for positive saving rates. To the extent that autonomous expenditures, whether consumption or investment, are externally financed, there is the possibility of their being financeconstrained - depending upon the 'elasticity' or accommodativeness of the financial system (see Kregel's 'finance motive' entry). But increases in expenditure independent of current income also can be financed from recurrent income; e.g., an autonomous increase in expenditure funded by a reduction in the personal or corporate propensity to save. Demand autonomous with respect to current realized income from production is the crucial thing, in order to give aggregate demand the leading role vis-à-vis aggregate supply, in the determination of economic activity levels. But in particular relation to the demand-side determination of growth, the endogeneity of capacity-creating investment with respect to the growth rate of aggregate demand gives rise to 'supermultipliers' incorporating some form or other of the accelerator. Theoretical analysis along these lines

\footnotetext{
${ }^{16}$ Also required is a robust basis for rejecting the idea of automatic equilibration of the economy at zero involuntary unemployment, under competitive conditions. This is what the critique of marginal productivity theory also provides since that theory is, simultaneously, a theory of functional distribution and a theory of supply-side determination of activity levels. It may be added that our position of course does not preclude endorsing or incorporating elements of contemporary economic analysis that are contingently associated with marginalism, but have no intrinsic connection with the marginal productivity theory.
} 
reveals complex dynamics in the interaction between aggregate demand, investment and capacity utilization (Serrano 1995; Freitas and Serrano 2015). ${ }^{17}$

Finally, with further regard to a desirable Keynesian policy approach into the future - adding, just a little, to what has already been said on this in section 5 - the fate of our world hinges decisively upon the trend and impact of climate change. As mentioned in the previous section, Keynes's policy sensibility is not entirely alien to this issue. The public investment that he saw as the key lever for maintaining full-employment effective demand has relevance today, in the imperative for largescale investment in Green infrastructure, broadly understood, as well as in R\&D, with a view to consumption change and technological change to enable drastic reductions in carbon emissions. Furthermore, if positive growth or positive growth in consumption per capita proves nevertheless environmentally unsustainable, one may recall Keynes's vision of a future of stationary consumption per capita, with any subsequent or ongoing productivity growth per worker realized in the form of (equitably distributed) reduction in labour-time worked. A stationary-state Keynesianism is possible (recalling also that Keynes includes a role for population control: $C W$ IX, 331). While a future of consumption satiation and dramatically reduced working hours, as Keynes imagines in 'Economic Possibilities for our Grandchildren', has been criticized as a false prediction (164-6), it was really more a normative hope than a descriptive forecast. After all, it is couched in terms of possibilities - and as a hope, it is more important to take seriously now than in 1930. A Green infrastructure programme obviously can form a key element of a fullemployment policy. It would also be desirable, and in the spirit of Keynes, to marry such policy with substantial and vigorous measures to address economic inequality. On the public outlays side, this is first and foremost about enabling equality of access to high-quality education, health services and housing; but much also needs to be done on the revenue-raising side, in establishing tax regimes that are effective in equitably distributing the incidence of taxation. Climate change and politico-economic inequality are the two most fundamental (and interacting) threats to our civilization, threatening more than 'merely' the bread-and-butter economic objectives of full employment and equitable distribution of material resources. Climate change together with the dynamics of economic inequality and political inequality - the latter two, also interacting, and mutually reinforcing - have the capacity to fundamentally undermine our polities and societies. Consider, for example, the ill consequences for the rule of law that result from the inequality of political power, deriving from economic inequality, when 'the one per cent' undertake wholesale purchase of politicians; and for another example, the increasing militarization of our societies in response to global mass population movements.

\footnotetext{
${ }^{17}$ To the extent that the synthesis of classical-Sraffian price and distribution theory and the principle of effective demand involves systems with equilibrium or normal profit rates, and a tendency towards equilibrium or normal capital-output ratios, it has a certain affinity with the stock-flow-consistent modelling approaches that, in their application to Post-Keynesian economics, were pioneered by Wynne Godley (Godley and Lavoie 2007; compare Lavoie 2013, 50, note 4). Both proceed in terms of equilibrium stockflow relationships.
} 
One may commend, in this context, Tony Judt's $(2009,96)$ notion of 'a social democracy of fear'. But we must give the last word to Keynes, who, in June 1936, gave expression to his middle-way political economy in terms of:

a strong desire and hope that we ... may discover how to combine an unlimited readiness to experiment with changes in political and economic methods and institutions, whilst preserving traditionalism and a sort of careful conservatism, thrifty of everything which has human experience behind it, in every branch of feeling and of action (CW XXVIII, 334).

\section{References}

Aspromourgos, T. (1986), On the Origins of the Term "Neoclassical", Cambridge Journal of Economics 10(3): 265-270.

Aspromourgos, T. (2004a), Sraffian Research Programmes and Unorthodox Economics, Review of Political Economy 16(2): 179-206.

Aspromourgos, T. (2004b), “The Functionless Investor": Keynes's Euthanasia of the Rentier Revisited. In History and Political Economy: Essays in Honour of P.D. Groenewegen, edited by T. Aspromourgos and J. Lodewijks, London, Routledge: 217-235.

Aspromourgos, T. (2007), Interest as an Artefact of Self-Validating Central Bank Beliefs, Metroeconomica 58(4): 514-535.

Aspromourgos, T. (2011), Can (and Should) Monetary Policy Pursue a Zero Real Interest Rate, Permanently?, Metroeconomica 62(4): 635-655.

Aspromourgos, T. (2012), Keynes's General Theory After 75 Years: Chapter 24 and the Character of "Keynesian" Policy, Economic Record 88 (Special Issue, June): 149-157.

Aspromourgos, T. (2013), Sraffa's System in Relation to Some Main Currents in Unorthodox Economics. In Sraffa's Legacy: Interpretations and Historical Perspectives (Sraffa and the Reconstruction of Economic Theory, vol. 3), edited by E.S. Levrero, A. Palumbo and A. Stirati. Basingstoke, Palgrave Macmillan: 15-33.

Aspromourgos, T. (2014a), Keynes, Employment Policy and the Question of Public Debt, Review of Political Economy 26(4): 574-593.

Aspromourgos, T. (2014b), Keynes, Lerner, and the Question of Public Debt, History of Political Economy 46(3): 409-433.

Aspromourgos, T. (2015), Thomas Piketty, the Future of Capitalism and the Theory of Distribution, Metroeconomica 66(2): 284-305.

Aspromourgos, T. (2018), Keynes, Public Debt and the Complex of Interest Rates, Journal of the History of Economic Thought 40(4): 493-512. 
Bellino, E. and Serrano, F. (2018), Gravitation of Market Prices Towards Normal Prices: Some New Results, Contributions to Political Economy 37(1): 25-64.

Brown-Collier, E.K. and Collier, B.E. (1995), What Keynes Really Said About Deficit Spending, Journal of Post Keynesian Economics 17(3): 341-355.

Bryce, R.B. (1988), Keynes During the Great Depression and World War II. In Keynes and Public Policy After Fifty Years, Volume 1: Economics and Policy, edited by O.F. Hamouda and J.N. Smithin, New York, New York University Press: 146-150.

Cairncross, A. (2004), Keynes, John Maynard, Baron Keynes (1883-1946). In Oxford Dictionary of National Biography, vol. 31, edited by H.C.G. Matthew and B. Harrison, Oxford, Oxford University Press: 483-498.

Cassidy, J. (2014), Elizabeth Warren's Moment, New York Review of Books 61(9): 4-8.

Cesaratto, S., Serrano, F., and Stirati, A. (2003), Technical Change, Effective Demand and Employment, Review of Political Economy 15(1): 33-52.

Clarke, P. (2009), Keynes: the Rise, Fall, and Return of the 20th Century's Most Influential Economist, New York, Bloomsbury.

Dimand, R.W. (1991), Keynes, Kalecki, Ricardian Equivalence, and the Real Balance Effect, Bulletin of Economic Research 43(3): 289-292.

Freitas, F. and Serrano, F. (2015), Growth Rate and Level Effects, the Stability of the Adjustment of Capacity to Demand and the Sraffian Supermultiplier, Review of Political Economy 27(3): 258-281.

Garegnani, P. (1978-79), Notes on Consumption, Investment and Effective Demand, Cambridge Journal of Economics 2(4) and 3(1): 335-353 and 63-82. Reprinted in (1983) Keynes's Economics and the Theory of Value and Distribution, edited by J. Eatwell and M. Milgate, London, Duckworth: 21-69.

Garegnani, P. (1983), Two Routes to Effective Demand: Comment on Kregel. In Distribution, Effective Demand and International Economic Relations, edited by J.A. Kregel, London, Macmillan: 69-80.

Garegnani, P. (1988), Capital and Effective Demand. In The Foundations of Keynesian Analysis, edited by A. Barrère, London, Macmillan: 197-230.

Garegnani, P. (1992), Some Notes for an Analysis of Accumulation. In Beyond the Steady State: a Revival of Growth Theory, edited by J. Halevi, D. Laibman, and E.J. Nell, New York, St Martin's: 47-71.

Garegnani, P. and Palumbo, A. (1998), Accumulation of Capital. In The Elgar Companion to Classical Economics, A-K, edited by H.D. Kurz and N. Salvadori, Cheltenham, UK, Elgar: 10-18.

Godley, W. and Lavoie, M. (2007), Monetary Economics: an Integrated Approach to Credit, Money, Income, Production and Wealth, Basingstoke, Palgrave Macmillan. 
Howson, S. and Moggridge, D.E. (eds) (1990), The Collected Papers of James Meade, Volume 4: The Cabinet Office Diary 1944-46, London, Unwin Hyman.

Institut für Marxismus-Leninismus (1967), Karl Marx Friedrich Engels Werke, vol. 35. Berlin, Dietz Verlag.

Judt, T. (2009), What is Living and What is Dead in Social Democracy?, New York Review of Books 56(20): 86-96.

Kalecki, M. (1944), The White Paper on Employment Policy, Bulletin of the Oxford University Institute of Statistics 6(8): 131-135.

Keynes, J.M. (1936), The General Theory of Employment, Interest and Money, London, Macmillan.

Keynes, J.M. (1937), Alternative Theories of the Rate of Interest, Economic Journal 47(June): 241-252.

Kregel, J.A. (1985), Budget Deficits, Stabilisation Policy and Liquidity Preference: Keynes's Post-War Policy Proposals. In Keynes's Relevance Today, edited by F. Vicarelli, London, Macmillan: 28-50.

Kurz, H.D. (1985), Effective Demand in a "Classical" Model of Value and Distribution: the Multiplier in a Sraffian Framework, The Manchester School 53(2): 121-137. Reprinted in Kurz (1990), Capital, Distribution and Effective Demand: Studies in the 'Classical’ Approach to Economic Theory, Cambridge, Polity: 173-191.

Lavoie, M. (2013), Sraffians, Other Post-Keynesians, and the Controversy Over Centres of Gravitation. In Sraffa and the Reconstruction of Economic Theory, Volume 3: Sraffa's Legacy: Interpretations and Historical Perspectives, edited by E.S. Levrero, A. Palumbo, and A. Stirati, Basingstoke, Palgrave Macmillan: 34-54.

Levrero, E.S., Palumbo, A., and Stirati, A. (eds) (2013), Sraffa and the Reconstruction of Economic Theory, Volume 2: Aggregate Demand, Policy Analysis and Growth, Basingstoke, Palgrave Macmillan.

Meek, R.L., Raphael, D.D., and Stein, P.G. (eds) (1978), The Glasgow Edition of the Works and Correspondence of Adam Smith, Volume V: Adam Smith. Lectures on Jurisprudence, Oxford, Clarendon.

Moggridge, D.E. (1992), Maynard Keynes: an Economist's Biography, London, Routledge.

Moggridge, D.E. (2010), Introduction to New Edition. In J.M. Keynes, Essays in Persuasion, Cambridge, Cambridge University Press: xx-xlvii.

Moggridge, D.E. et al. (eds) (1971-1989), The Collected Writings of John Maynard Keynes, 30 vols, London, Macmillan and New York, Cambridge University Press.

Panico, C. (1988), Interest and Profit in the Theories of Value and Distribution, London, Macmillan. 
Pasinetti, L.L. (1981), Structural Change and Economic Growth: a Theoretical Essay on the Dynamics of the Wealth of Nations, Cambridge, Cambridge University Press.

Pasinetti, L.L. (2007), Keynes and the Cambridge Keynesians: a 'Revolution in Economics' to be Accomplished, Cambridge, Cambridge University Press.

Patinkin, D. (1987), Real Balances. In The New Palgrave: a Dictionary of Economics, vol. 4, edited by J. Eatwell, M. Milgate and P. Newman, London, Macmillan: 98-101. Reprinted in (2008) The New Palgrave Dictionary of Economics, 2nd edn, edited by S.N. Durlauf and L.E. Blume, Basingstoke, Palgrave Macmillan: 11324-11328.

Petri, F. (2004), General Equilibrium, Capital and Macroeconomics: a Key to Recent Controversies in Equilibrium Theory, Cheltenham, UK, Elgar.

Robinson, A. (1977), A Comment. In Keynes versus the 'Keynesians' ...?, edited by T.W. Hutchison, London, Institute of Economic Affairs: 58-60.

Sayers, R.S. (1976), The Bank of England, 1891-1944, vol. 1, Cambridge, Cambridge University Press.

Schefold, B. (1997), Normal Prices, Technical Change and Accumulation, London, Macmillan.

Serrano, F. (1995), Long Period Effective Demand and the Sraffian Supermultiplier, Contributions to Political Economy 14(1): 67-90.

Skidelsky, R. (1983), Hopes Betrayed, 1883-1920 (John Maynard Keynes, vol. I), London, Macmillan.

Skidelsky, R. (2009), Keynes: the Return of the Master, London, Allen Lane.

Smith, M. (2012), Demand-Led Growth Theory: a Historical Approach, Review of Political Economy 24(4): 543-573.

Steedman, I. (1992), Questions for Kaleckians, Review of Political Economy 4(2): 125-151.

Tinbergen, J. (1939), Statistical Testing of Business-Cycle Theories, 2 vols, Geneva, League of Nations.

Varoufakis, Y. (2017), Adults in the Room: My Battle with Europe's Deep Establishment, London, The Bodley Head. 


\section{Author contact information:}

Tony Aspromourgos

School of Economics, University of Sydney.

NSW 2006 Sydney - (Australia)

tony.aspromourgos@sydney.edu.au 